NBER WORKING PAPER SERIES

FOREIGN FIRMS AND INDONESIAN

MANUFACTURING WAGES:

AN ANALYSIS WITH PANEL DATA

Robert E. Lipsey

Frederik Sjöholm

Working Paper 9417

http://www.nber.org/papers/w9417

\author{
NATIONAL BUREAU OF ECONOMIC RESEARCH \\ 1050 Massachusetts Avenue \\ Cambridge, MA 02138 \\ December 2002
}

The authors wish to thank participants at an ICSEAD seminar in Japan, a CEPR conference in Greece, the IT\&FA meeting in Bangkok, the EAEA conference in Kuala Lumpur and a workshop on "Technology and Foreign Ownership" in Norway. An earlier version of this paper was prepared as part of an ICSEAD project on "Foreign Multinational Corporations and Host-Country Labor Markets in Asia". We are grateful to Sadayuki Takii for cleaning the data. The views expressed herein are those of the authors and not necessarily those of the National Bureau of Economic Research.

(C) 2002 by Robert E. Lipsey and Frederik Sjöholm. All rights reserved. Short sections of text not to exceed two paragraphs, may be quoted without explicit permission provided that full credit including, (C) notice, is given to the source. 
Foreign Firms and Indonesian Manufacturing Wages: An Analysis With Panel Data

Robert E. Lipsey and Fredrik Sjöholm

NBER Working Paper No. 9416

December 2002, Revised June 2006

JEL No. O12, F23, J31

\begin{abstract}
$\underline{\text { ABSTRACT }}$
Wages in domestically- owned Indonesian manufacturing plants taken over by foreign firms increased sharply between the year before takeover and two years after takeover, relative to plants remaining in domestic ownership. Blue- collar wage levels in these plants had been less than 10 per cent above and white- collar wages more than 10 per cent below those in their industries a year before takeover. Two years after takeover both were more than 50 per cent above average. Wages in foreign plants taken over by domestic owners tended to rise less than average for their industries, although they remained above the domestic average. Thus, foreign firms did not select particularly high- wage plants to take over and it was foreign takeovers, rather than takeovers in general, that led to large wage increases and high wages.

An econometric analysis of the whole panel found that both foreign ownership throughout the period and foreign takeover resulted in higher wages relative to domestically- owned plants. The wage effects for white- collar employees were typically around twice those for blue- collar employees. Foreign takeovers were associated with large increases in blue- collar employment and both foreign and domestic takeovers with declines in white- collar employment. However, the employment changes were not strongly related to the wage changes.
\end{abstract}

Robert E. Lipsey

National Bureau of Economic Research 365 Fifth Ave. Suite 5318

New York, NY 10016

and NBER

Rlipsey@gc.cuny.edu
Fredrik Sjöholm

European Institute for Japanese Studies

Stockholm School of Economics

P.O. Box 6501, S-113 83 Stockholm

SWEDEN

Fredrik.Sjoholm@hhs.se 


\section{FOREIGN FIRMS AND INDONESIAN MANUFACTURING WAGES: \\ AN ANALYSIS WITH PANEL DATA}

\section{Fredrik Sjöholm and Robert E. Lipsey}

\section{Introduction}

Many studies have found that affiliates of foreign firms pay higher wages than locallyowned firms in their host countries. That is generally true in both developed and developing host countries. ${ }^{1}$ In most cases, some margin in favor of employees of foreign- owned firms remains even after industry, location, and establishment characteristics are taken into account. ${ }^{2}$ In one of the few cases in which labor quality could be taken into account, beyond the distinction between production and non- production workers, it still seemed clear that foreign firms in Indonesia paid a wage premium in 1996 (Lipsey and Sjöholm 2004).

There are several suggestions as to why foreign firms would pay higher wages than domestic firms. For instance, foreign firms might try to prevent technological spillovers through labor turnover by paying a wage premium (Fosfuri, Motta, and Ronde 2001); the wage premium might be caused by rent-sharing arrangements between foreign firms and their employees (Budd, Konings, and Slaughter 2005); as compensation for a higher labor demand volatility in foreign plants (Fabri, Haskel, and Slaughter 2003); or as compensation for a higher foreign plant closure rate (Bernard and Sjöholm 2003).

\footnotetext{
${ }^{1}$ See for instance Aitken, Harrison, and Lipsey (1997), Doms and Jensen (1998), Feliciano and Lipsey (2006), and Girma, Greenaway, and Wakelin (2001).

${ }^{2}$ See Lipsey (2004) for a summary of the literature on FDI and wages.
} 
However, while the existence of higher wages in foreign- owned plants is well documented, it would be premature to conclude from that fact alone that foreign ownership causes high wages. For example, the correlation between foreign ownership and wages is sometimes attributed to selectivity bias: the selection of high- wage establishments for acquisition by foreign firms, so called "cherry-picking". There may be unmeasured characteristics of individual firms or establishments that are associated with both high wages and foreign ownership. From a host-country policy perspective, it is clearly the question of whether FDI causes high wages that is of interest.

Another possibility is that wages in foreign-owned firms are higher than those in domestically-owned firms because many of the cases of foreign ownership result from takeovers of existing firms, rather than new establishments, and there is a considerable literature, mainly referring to developed countries, that finds that acquisitions themselves result in wage increases, regardless of the nationality of the acquiring firms. For instance, Brown and Medoff (1988) find a positive wage effect of acquisitions in the state of Michigan in the US, as do McGuckin, Nguyen, Sang, and Reznek (1995) for acquisitions in the American food industry. Lichtenberg and Siegel (1992), in a study of acquisitions in the American manufacturing sector find a negative effect on white collar wages and no effect on blue collar wages. One possible explanation to a general positive effect of takeovers on wages could be a strategy by new owners to keep personnel and their firm specific knowledge in the company (Heyman, Sjöholm, and Tingvall 2006, p.18). Such knowledge of the firm and its networks might be essential if the new owners are to make a profit from a new firm. Secondly, an acquisition might also be taken as an opportunity to renegotiate contracts and to perform organizational changes (Schleifer and Summers, 1988; Bertrand and Mullainathan, 2003). Ownership changes are typically followed 
by a "shake out": a period of rationalizations. The remaining workers might require a wage premium to stay with the company during such changes.

One implication for our study is that the increased wages after foreign takeovers might be caused by two different components. One is the fact of takeover itself and the other is the change to foreign ownership. We try to distinguish between these by examining foreign and domestic takeovers separately.

We attempt here to establish as conclusively as possible whether foreign ownership itself raised wages in the Indonesian manufacturing sector. Our advantage in this effort comes mainly from the fact that we can use panel data in place of the cross-sectional data that has been used in previous studies. With this long panel of Indonesian data, and our ability to follow establishments after both foreign and domestic takeovers, we demonstrate that foreign ownership or acquisition of an Indonesian manufacturing plant results in higher wages for the plant's employees, and that domestic acquisitions of foreign-owned plants do not result in corresponding wage gains. This is an important issue not only academically, but for countries deciding on policies toward foreign ownership.

\section{Panel data on Indonesian manufacturing}

We analyze Indonesian manufacturing data supplied by the Indonesian Statistical Office. The data include all manufacturing plants with more than 20 employees in any of the years 19751999. Inclusion of plant identification codes enables us to construct a panel and follow the plants over time. The number of plants in the Indonesian manufacturing sector increased from 7,355 in 
1975 to 22,041 in 1999 and the number of plants with foreign ownership from 263 to $1,710{ }^{3}$ The maximum time a plant could be present is 24 years, if the plant existed in 1975 . However, most plants were established after 1987, so that their maximum period would be 12 years or less. The average period in the sample is 7.6 years and the median, 6 years. The exit rate is about 7 percent, indicating that plants that enter the manufacturing sector tended to remain.

The foreign share of Indonesian manufacturing employment and value added is shown in table 1 . The foreign share in 1985 was only ten percent of employment and 21 percent of value added. However, an economic crisis in the mid 1980s, caused by falling prices of oil and other raw materials, forced Indonesia to liberalize its FDI regime from around 1986. The result was a sharp increase in the relative importance of FDI, to about 21 percent of employment and 36 percent of value added in 1999. The foreign presence is relative low in Food products, Wood products, and Paper and Pulp, and relative high in Basic Metal Industries, Fabricated Metal Products and Other Industries.

Real wages grew over the period 1975-99, by almost 200 percent for white-collar workers and around 130 percent for blue-collar workers. The wage ratios between foreign owned and private-domestically owned plants are shown in table 2. In 1975, wages were about three times as high in foreign- owned plants as in private domestic plants. The wage differences have gradually decreased over time and in 1999 were 44 percent for blue-collar workers and 68 percent for white-collar workers. The difference in blue collar- wages has been high in Food products, Paper and Pulp, Chemicals and Non-Metallic Minerals, and in white-collar wages in Food products, Non-Metallic Minerals, Fabricated Metal Industries, and Other Industries.

\footnotetext{
${ }^{3}$ A foreign plant is defined as one with any foreign ownership. Most foreign plants are joint ventures with a majority foreign ownership.
} 
White-collar wages have sometimes been higher in private domestic than in foreign- owned plants in Basic Metal Products. ${ }^{4}$

A frequently mentioned source of possible selectivity bias is foreign takeovers of highwage domestically- owned plants. If foreign firms tended to take over the plants with the highest average wage, either nationally, within industries, within regions, or within industries within regions, a cross- section analysis would find that foreign- owned establishments paid higher wages than domestically- owned establishments. However, increases in foreign shares would have no effect on average wages and would be associated with lower wages in domesticallyowned plants.

The best way to judge the effects of foreign ownership is to follow cases in which takeovers took place. We first examine wage levels in target plants before takeovers to learn whether it is the selection of domestic firms for takeover that produces the higher wages observed in foreign- owned plants. We then calculate the changes in wage levels that followed takeovers, relative to wage changes in domestically- owned Indonesian manufacturing plants, to see whether differential wage changes could account for the higher wages in foreign-owned plants.

Table 3 shows the number of domestic takeovers of foreign-owned plants and the number of foreign takeovers of domestically-owned plants from 1975 to 1999 . Foreign takeover is defined as an ownership change where the foreign ownership goes from zero to a positive value. Domestic takeover is defined as an ownership change where the foreign ownership goes from a positive value to zero. Both types of takeovers typically include plants with majority foreign ownership: the average foreign ownership share is 76 percent in foreign takeovers and 73 percent

\footnotetext{
${ }^{4}$ See Hill (1990) and Manning (1998) for other studies on wages in Indonesian manufacturing.
} 
in firms the year before a domestic takeover. Fewer than one percent of the total number of plants changed ownership from domestic to foreign or from foreign to domestic in each year. However, the number increased over time, especially foreign takeovers. They grew from an average of 23 per year between 1975-1989 to 90 per year between 1990-1999. The sharp increase in foreign takeovers was caused by the previously mentioned liberalization of the FDI regime that has taken place in Indonesia since the mid 1980s. Domestic takeovers of foreignowned plants also increased, but not as much, from 29 per year in the first period to 64 per year in the 1990s.

Plants involved in takeovers in both directions, foreign of domestically-owned plants and domestic of foreign-owned plants, were larger, on average, than existing domestically-owned plants, overall and in almost every industry group in each period. However, takeovers in both directions were considerably smaller than existing foreign-owned plants. Foreign takeovers were, on average larger than domestic takeovers, but the margin was small overall and not consistent among industry groups. Thus, with respect to size, takeovers were not a random selection among domestically-owned or foreign-owned plants. Foreign takeovers were biased toward the larger domestically-owned plants and domestic takeovers toward the smaller foreign-owned plants.

Table 4 answers the question as to whether foreign firms paid high wages on average simply because they took over high-wage local firms. The table shows the wages one year and two years before a foreign takeover of a private domestically-owned plant relative to wages in all private domestically-owned plants, within the same industry and in the same year. It also shows the same information for foreign-owned plants that were taken over by domestic owners.

Plants taken over by foreigners paid blue collar wages somewhat above the average in all privately owned plants. The differentials were in the range of 10 to 20 per cent, far below the 
differential in table 2. In no case was the differential statistically significant. For white-collar employees, the contrast was even more striking. While existing foreign-owned plants paid 60-70 per cent more to such employees, the target firms, before takeover, had been paying them about average wages for privately-owned plants. Thus there is no evidence that the differentials in existing plants resulted from selective acquisition of high- wage domestically-owned plants.

The evidence for selectivity relative to domestic wage levels (but not foreign- owned plant wage levels) is stronger for domestic takeovers of foreign-owned plants. White-collar wages in domestic takeovers were at about average for domestically-owned plants, but bluecollar wages were about 30 per cent higher. However, although domestic firms were acquiring foreign-owned plants with blue-collar wage levels well above average domestic levels, they were not as much above as in the average foreign plant, and the margin over domestically-owned plants was not statistically significant, except in two industries, Food Products and Chemicals, where both blue and white-collar wages were significantly above the domestic plant averages. Thus, domestic takeovers of foreign- owned plants were of plants that paid relatively low wages for foreign- owned plants, particularly relatively low white- collar wages, except in Food products and Chemicals.

Taken together, the two sets of averages suggest, first, that any tendency of foreign takeovers of domestic plants to be biased toward high-wage domestic plants was slight and did not come close to accounting for most of the differentials found in existing plants between foreign and domestic owners. Second, the fact that domestic takeovers of foreign-owned plants were biased toward plants with higher wages than existing domestic plants tended to reduce the wage differential between foreign-owned and domestically-owned plants. 
Given the starting point for foreign takeovers described in Table 4, we can observe the events that followed for the target plants in Table 5. For manufacturing as a whole, domestically-owned plants taken over by foreign firms enjoyed large wage increases relative to existing domestically- owned plants. Blue-collar wages, which had been about 20 per cent above average, unweighted, before takeover, increased by 30 percentage points relative to average domestic plant wages, averaging around 50 per cent higher after 2 years of foreign ownership, although neither of these margins was statistically significant. Weighted by sector employment, they had been only 5- 10 per cent above average before foreign takeover but were 63 per cent higher two years after takeover, and both these margins were statistically significant. Whitecollar wage levels, had been close to average before takeover, unweighted, and about 10 per cent below, weighted. They rose even faster after takeover than blue- collar wages. After 2 years of foreign ownership, wages in the target plants were 84 per cent higher than average white-collar wages, unweighted, and 59 per cent higher, weighted, but only the difference in the unweighted ratios was significant.

There is a lot of variation among the five industry groups for which there are sufficient numbers of observations. Blue-collar wages increased significantly relative to industry average wages in three of the five and white-collar wages in four out of five. After two years of foreign ownership, outside of industry group 33, wages in foreign-owned target plants ranged from 30 to more than 100 per cent above the average in private domestically-owned plants, and in half the cases, the difference was statistically significant, at least at the 10 per cent level.

The story was very different in plants that passed from foreign to domestic ownership. Blue-collar wages, which had been about 30 per cent above the average in private domesticallyowned plants when these plants were foreign- owned, rose more slowly than average and after 
two years of domestic ownership were only around 17 per cent above average, both weighted and unweighted. However, it should be noted that differences in blue-collar wages are statistically insignificant both before and after the takeover. White-collar wages rose but not significantly, according to the unweighted comparisons, and remained the same in relative terms according to the weighted calculations. After two years of domestic ownership, they were still somewhat above domestic average wages, but by nowhere near as much as the wages in the plants moving into foreign ownership or the plants in foreign ownership throughout our period. In the five industry groups, seven out of 10 comparisons show declines in wage levels, two significantly, relative to the averages. Four out of the ten comparisons showed these plants to have lower than average wage levels after a period of domestic ownership, although none significantly.

The simple comparison between foreign takeovers with takeovers by domestic firms is one test of whether the wage increases we see in the former group are the result simply of takeovers, regardless of ownership. The results suggest that the change to foreign ownership rather than the change in ownership itself is the main source of the wage increases that produced high wage levels.

\section{Econometric Estimations}

The previous discussion suggests that foreign plants pay relative high wages and that foreign takeovers of domestic plants raise both blue- and white-collar wages. Moreover it seemed that high wages before takeover in domestic plants acquired by foreigners explain only a very minor part of the higher wages in foreign plants. We continue with an econometric analysis 
to further examine the wage difference by estimating different variations of the following equation:

$\ln \mathrm{W}_{i t}=\beta$ ownership $_{i t}+\lambda \ln \mathrm{X}_{i t}+$ Sector + Region + Time $+\sigma_{i t}+\varepsilon_{i t}$.

where $i$ and $t$ index plants and years respectively. $W$ is average plant wage, and ownership is a dummy variable for foreign or government ownership. ${ }^{5} X$ is a vector with plant specific characteristics such as size, and the use of electricity and other inputs. Sector dummy variables, at a 2-digit level of ISIC, regional dummy variables, and time dummy variables control for sector, regional or time specific wage effects. $\sigma$ is a plant specific effect, which will be estimated both as a random and as a fixed effect.

The effect of foreign ownership on wages estimated from Equation 1 is seen in table 6. The results in the first two columns, within industries, regions, and years, show that foreignowned establishments paid 0.67 more in log terms (about 95 percent) for blue- collar workers and 0.90 more in log terms (about 150 percent) for white- collar workers. Some of that difference is associated with the characteristics of the individual plants, such as their size and their inputs of energy (as a proxy for capital intensity), and other intermediate inputs, all of which are correlated with their ownership. If we include these characteristics as explanatory variables, thus attributing the association with wages to them, rather than to foreign ownership, the differential is much reduced, to around .29 for blue- collar workers and over .43 for white- collar workers (columns 2 and 3). Finally, the fixed effect estimates examine variations within plants. Variables that do not change over time will be fully absorbed by the plant specific fixed effects. In equations with

\footnotetext{
${ }^{5}$ Foreign plants include plants with any amount of foreign ownership. Government ownership is defined as plants with no foreign ownership and any amount of government ownership.
} 
plant-specific fixed effects, foreign ownership represents wages only in the foreign ownership period of plants that changed ownership, and these wage levels are compared with each plant's wages when it was domestically owned. Hence, the coefficient captures the effect of foreign ownership both in plants moving from foreign to domestic ownership, and in plants moving from domestic to foreign ownership. If plant fixed effects are introduced, along with plant characteristics, as in the last two columns, the remaining differentials are around .10 and 21 .

We also tried to include random effect estimations but the assumption of no correlation between the error term and the independent variables was strongly rejected by a Hausman test.

Plants with any foreign equity are classified as foreign owned in the above analysis. The effect on wages might differ depending on the share of foreign ownership. ${ }^{6}$ For instance, a majority foreign ownership share might be required for bringing in technologies from the parent firm, which in turn might cause a higher wage premium in such foreign majority owned plants. We therefore divide foreign ownership in plants with a majority foreign ownership share and plants with a minority foreign share. The results are shown in table 7. Both majority- and minority owned foreign plants pay higher wages than local plants. Majority-owned plants pay higher wages than minority-owned plants for white collar workers but lower for blue collar workers. None of the differences between foreign majority- and minority wages are significant at a five per cent level. Further estimations showed that as little as a five percent foreign equity share resulted in a statistically significant wage premium (not shown).

\footnotetext{
${ }^{6}$ Takii and Ramstetter (2005) find, for instance, a difference in productivity levels among Indonesian plants depending on the share of foreign ownership, where majority foreign ownership is associated with relatively high levels of productivity.
} 
As previously mentioned, the Indonesian manufacturing sector has changed substantially over the studied period. For instance, the period up until the mid-1980s was characterized by import substitution policies, and foreign firms present in Indonesia during this time were primarily supplying the domestic market. Since then, Indonesia has become increasingly more open, resulting in large inflows of export oriented FDI. It is possible that the wage premium differs between the two trade regimes. For instance, foreign firms may have made large rents during the import substitution period and shared part of these rents with their workers. On the other hand, labor markets may have become more competitive in the later, more open period, increasing the competition for the best workers. We therefore divide our sample in two subperiods in table 7. There was a significant wage premium for blue-collar wages only in the latter, outward- oriented period, and a relative high wage premium for white-collar workers also in that period. $^{7}$

In table 8 , we divide foreign-owned plants into three groups. ${ }^{8}$ One is "foreign since 1975 ", plants that have been foreign- owned throughout the period they are in our data. A second is "foreign takeovers", plants that had previously been domestically owned during the period, but are observed after foreign takeover. The third is "foreign, pre-domestic takeover" which is foreign-owned plants that were later taken over by domestic owners, observed in the period prior to domestic takeover. The "foreign since 1975" category includes plants established as foreign- owned during our period and never taken over by domestic firms, but also plants that

\footnotetext{
${ }^{7}$ Note, however, that the wage premium for white-collar workers in foreign plants is not statistically different at a five percent level between the two periods.

${ }^{8} \mathrm{We}$ are greatly indebted to a referee for suggesting this procedure.
} 
were established or taken over by foreign firms before 1975, and never changed to domestic ownership. ${ }^{9}$

We also divide domestically-owned plants into "domestic, pre-foreign takeover," those that were later acquired by foreign firms, observed during their pre-takeover life, and "domestic takeovers," those that had been foreign-owned during our period, but were taken over by domestic firms, observed after domestic takeover. The category with no dummy variable, the omitted category, is establishments that were domestically-owned throughout the period

It is seen that plants taken over by foreign owners, after takeovers, as well as plants that had always been foreign owned, paid comparatively high wages. The wage premium, relative to plants that were always domestic during our period, in foreign takeovers is 0.49 in $\log$ terms for blue-collar wages and 0.74 in log terms for white-collar wages, broadly in line with the results in Table 6 for foreign ownership in general. This might be seen as the total relative wage effect from foreign takeovers. However, some of this effect is associated with an increase in size or by changes in other plant characteristics after a change in ownership. Controlling for such changes can be thought of as capturing the "pure" effect of ownership changes. This explains why the relative wage differences decrease to about .23 for blue-collar wages and .37 for white-collar wages after inclusion of the control variables. The coefficients for Foreign takeovers are only marginally smaller than for Foreign since 1975. That suggests that relative wages in formerly domestic-private plants converge towards wages in established foreign plants after the domestic plants are taken over by foreign firms. The coefficients for Domestic takeover are positive and

\footnotetext{
${ }^{9}$ We experimented with excluding plants with foreign ownership in 1975 since we cannot be sure they haven't been taken over in a previous year. The exclusion did not have much effect on the results.
} 
statistically significant at around .06 and .10 when plant characteristics are included, much smaller than the coefficients for foreign takeovers, and considerably smaller than the coefficients for Foreign pre-domestic takeover. Thus, after domestic takeovers, wages fell relative to those in plants in domestic hands since 1975, but remained above those in plants remaining in domestic hands.

The fixed effect estimates answer a different question. They reflect differences in absolute wage levels rather than in wages relative to those in plants domestically-owned throughout. Plants that were objects of foreign takeovers had post-acquisition blue-collar wages higher than pre-acquisition wages by about .17 and white-collar wages higher by about .33 . These estimates also suggest a positive effect on absolute wage levels from domestic takeovers, but substantially smaller than from foreign takeovers. Post-acquisition wages in domestic takeovers were higher than pre-acquisition wages by .04 for blue-collar workers and .07 for white-collar workers, about one quarter of the differences between pre-acquisition and postacquisition wages in foreign takeovers.

It can also be noted that in the fixed-effect equations in Table 8, as well as in Tables 6 and 7, the effect of size on blue-collar wages is negative, implying that the additional blue-collar workers added in employment expansions are hired at lower wages than existing workers, but that is not the case for white-collar workers. For them, larger size seems to be associated with higher wage levels.

Selectivity bias in takeovers might be a source of concern; for example, takeovers of Indonesian plants by foreign owners might not be a random process but might be caused by some factor that would have an effect on wages even without the takeover. The standard procedure to 
address selectivity concerns is through an instrumental variable (IV) approach. ${ }^{10}$ However, we were unsuccessful in attempts to derive IV estimates. One problem is that the share of takeovers, foreign- and domestic, is less than one percent of the total number of plants. Moreover, most variables that affect takeovers, such as size, are also correlated with wages and therefore not suitable as instruments. As a result, we can only note that selectivity in takeovers could conceivably be a source of bias.

Since most takeovers are concentrated in a few sectors, we run the fixed effects estimations for absolute wage levels at a sector level in table 9. There are positive effects of foreign takeovers on absolute wages in all five sectors, ranging between .11 and .24 for bluecollar wages and between .20 and .44 for white-collar wages. The result for domestic takeovers is less clear, with a positive and statistically significant coefficient for blue-collar wages in three sectors and a negative and significant in two, and a positive effect for white-collar wages in two sectors, and a negative in one. Hence, it seems that foreign takeovers have a substantial positive effect on absolute average wages across the whole range of industries.

This finding that average wages rise after takeovers does not necessarily imply that individual workers' wages increase with foreign ownership. An increase in the average wage might come, for example, through the dismissal of low-wage workers. We therefore examined changes in employment after takeovers (not shown). Foreign takeovers consistently raised the number of blue-collar workers and reduced the number of white-collar workers. Domestic

\footnotetext{
${ }^{10}$ An alternative would be to use Heckman's $(1978,1979)$ method for endogeneity bias corrected OLS estimator. However, Vella and Verbeek (1999) have shown that the IV method generates comparable estimates. See also Conyon, Girma, Thompson, and Wright (2002: 99-
} 100). 
takeovers of foreign owned plants had a consistent negative effect on the number of white-collar workers and a more uncertain effect on the number of blue-collar workers. However, including growth in employment in the regressions has only a marginal effect on the coefficient for Foreign takeovers and no effect on the coefficient for Domestic takeovers. The implication is that the change in employment is not the major explanation for the change in wages following a takeover. $^{11}$

It is conceivable that there might have been average wage effects from the substitution of more highly educated workers for those with less education. Unfortunately, data on worker education levels are available for only a few years. Within the one and two- year spans covered by the education data, there are no indications of major changes in the education mix of the labor force after foreign takeovers (Lipsey and Sjöholm 2002). However, we cannot be certain that worker education levels did not change sharply in other periods.

\section{Concluding Remarks}

Foreign - owned establishments in Indonesia, as in other countries, pay higher wages than domestically- owned establishments, even when industry, region, plant characteristics, and worker characteristics are taken into account. What has not been so obvious is whether these higher wages are a consequence of foreign ownership itself or are associated with persistent plant characteristics, unknown in nature, but not determined by foreign ownership. This paper examines the question in two ways. The first involves separating firms into those taken over by foreigners from domestic owners, those taken over by domestic owners from foreigners, and

\footnotetext{
${ }^{11}$ See the working paper version of this paper for more information on the change in employment after takeovers and how this affects wages (Lipsey and Sjöholm 2002).
} 
those not changing ownership. We examine wage levels in establishments before they are taken over, to learn whether foreign firms select high- wage plants to acquire, and we examine wage changes after takeover. We conclude from these simple mean comparisons that, while establishments acquired by foreigners had previously paid somewhat above-average blue-collar, but not white-collar, wages, the differences were far too small to account for the wage differences between foreign-owned and domestically-owned plants in general.

The second method involves an econometric analysis of the relation of average plant wage levels to foreign ownership and changes in foreign ownership, taking account of other influences on wage levels.

Foreign firms tended to take over large domestic plants. These plants had above average domestic-private blue-collar wages, although not as high as those in foreign- owned plants in general, and slightly above average white-collar wages. After foreign takeovers, both white collar and blue-collar wages in these plants rose strongly, especially the white- collar wages.

Domestic takeovers targeted relatively small foreign plants with blue- and white-collar wages that were lower than the foreign average but higher than the domestic average. The effect of domestic takeovers on wages is unclear; often positive but small, and at times negative. Hence, it does not seem to be takeovers themselves that explains most of the increased wages, but the change in ownership from domestic to foreign.

An econometric analysis of wages using the whole panel of data, found that foreign ownership, in an equation that included time, industry, and region dummies, was associated with blue collar wages two- thirds higher than in domestically- owned private plants, and white- collar wages almost twice as high. Many of these wage differences were associated with plant 
characteristics, such as size and input use, and when these were introduced, the foreign plant margins were reduced to about 30 and 40 per cent.

A further analysis distinguished plants taken over during the period from those foreignowned throughout the period and from domestic takeovers. It found that both foreign ownership and foreign takeover result in blue- collar wages about 30 per cent above the average for private plants remaining domestically-owned throughout, and white- collar wages 40 to 45 per cent higher, even holding constant time, industry, and region. Domestic takeovers of foreign-owned plants resulted in small increases in absolute wage levels, but declines relative to plants always remaining domestically-owned, although wages remained above the average domestic plant level.

From all of these analyses, we conclude that foreign ownership or acquisition of an Indonesian manufacturing plant results in higher wages for the plant's employees, and that domestic acquisitions of foreign-owned plants do not result in corresponding wage gains. Foreign ownership and foreign acquisition increase wages relative to domestic ownership and even domestic acquisition. 


\section{References}

Aitken, Brian, Anne E. Harrison, and Robert E. Lipsey. 1996. "Wages and Foreign Ownership: A Comparative Study of Mexico, Venezuela, and the United States.” Journal of International Economics 40: 345-71.

Bernard, Andrew B. and Fredrik Sjöholm. 2003. "Foreign Owners and Plant Survival.” NBER Working Paper No. 10039.

Bertrand, M., and Mullainathan, S., (2003), "Enjoying the Quiet Life? Corporate Governance and Managerial Control”, Journal of Political Economy, 111(51), 1043-1076.

Brown, Charles, and James L. Medoff. 1988. "The Impact of Firm Acquisition on Labor.” In Corporate Takeovers: Causes and Consequences, ed. Alan J. Auerbach. Chicago: The University of Chicago Press.

Budd, John W., Josef Konings and Matthew J. Slaughter. 2005. "International Rent Sharing in Multinational Firms.” Review of Economics and Statistics 87: 73-84.

Conyon, Martin, Sourafel Girma, Steve Thompson, and Peter Wright. 2002. "The Impact of Foreign Acquisition on Wages and Productivity in the United Kingdom.” Journal of Industrial Economics 50: 85-102.

Doms, Mark E., and J. Bradford Jensen. 1998. "Comparing Wages, Skills, and Productivity Between Domestically and Foreign-Owned Manufacturing Establishments in the United States.”, In Geography and Ownership as Bases for Economic Accounting, ed. Robert E. Baldwin, Robert

E. Lipsey and J. David Richardson. Chicago: University of Chicago Press, pp. 235-255.

Fabri, Francesca, Jonathan E. Haskel and Matthew J. Slaughter. 2003. "Does Nationality of Ownership Matter for Labor Demands?” Journal of the European Economic Association, Papers and Proceedings 1: 698-707. 
Feliciano, Zadia, and Robert E. Lipsey. 2006. "Foreign Ownership, Wages, and Wage Changes in the United States, 1987-1992." Contemporary Economic Policy, 24: 74-91..

Fosfuri, Andrea, Motta Massimo, and Thomas Ronde. 2001. "Foreign Direct Investments and Spillovers through Workers’ Mobility.” Journal of International Economics 53:.205-222.

Girma, Sourafel, David Greenaway, and Katharine Wakelin. 2001. "Who Benefits from Foreign Direct Investment in the UK?" The Scottish Journal of Political Economy 48: 119-134.

Girma, Sourafel, and Holger Görg. 2001. "Blessing or Curse? Domestic Plant's Survival and Employment Prospects After Foreign Acquisition.” Working Paper No 2001/18, Leverhulme Centre for Research on Globalisation and Economic Policy, School of Economics, University of Nottingham.

Heckman, James J. 1978. "Dummy Endogenous Variables in a Simultaneous Equation System.” Econometrica 46: 931-959.

Heckman, James J. 1979. "Sample Selection Bias as a Specification Error.” Econometrica 47: 162.

Heyman, Fredrik, Sjöholm, Fredrik, and Patrik Gustavsson-Tingvall. 2006. ”Acquisitions, Multinationals, and Wage Dispersion.” EIJS Working Paper No. 222, Stockholm School of Economics.

Hill, Hal. 1990. “Indonesia's Industrial Transformation Part II.” Bulletin of Indonesian Economic Studies 26: 75-109.

Huizinga, Harry. 1990. "Unions, Taxes and the Structure of Multinational Enterprises.” Economic Letters 34: 73-75.

Lichtenberg, Frank, and Donald Siegel. 1992. “Takeovers and Corporate Overhead.” In Corporate Takeovers and Productivity, ed. Frank Lichtenberg. Cambridge, MA: The MIT Press. 
Lipsey, Robert E. 2004. "Home- and Host-Country Effects of Foreign Direct Investment." In Challenges to Globalization, ed. Robert E. Baldwin and L. Alan Winters. Chicago, University of Chicago Press.

Lipsey, Robert E. and Fredrik Sjöholm. 2002. "Foreign Firms and Indonesian Manufacturing Wages: An Analysis With Panel Data." Cambridge, MA, NBER Working Paper, No. 9417.

Lipsey, Robert E., and Fredrik Sjöholm. 2004. "Foreign Direct Investment, Education, and Wages in Indonesian Manufacturing." Journal of Development Economics 73: 415-422.

Manning, Chris. 1998. Indonesian Labour in Transition: An East Asian Success Story? Cambridge: Cambridge University Press.

McGuckin, Robert H., Nguyen, Sang V., and A.P. Reznek. 1995. “The Impact of Ownership Change on Employment, Wages and Labor Productivity in US Manufacturing 1977 1987.” Washington, D.C., Center for Economic Studies, US Bureau of the Census..

Shleifer, A., and Summers, L.H., (1988), "Breach of Trust in Hostile Takeovers", In Corporate Takeovers: Causes and Consequences, Ed. A.J. Auerbach. Chicago: University of Chicago Press.

Takii, Sadayuki and Eric D. Ramstetter. 2005. "Multinational Presence and Labour Productivity Differentials in Indonesian Manufacturing, 1975-2001." Bulletin of Indonesian Economic Studies 41: 221-242.

Vella, Francis, and Marno Verbeek. 1999. "Estimating and Interpreting Models with Endogenous Treatment Effects." Journal of Business and Economic Statistics 17: 473-478. 


\section{TABLE 1}

\section{THE FOREIGN SHARE OF INDONESIAN MANUFACTURING INDUSTRY BETWEEN 1975-1999 AT A 2-DIGIT LEVEL OF ISIC (\%)}

\begin{tabular}{|l|l|ll|ll|ll|ll|}
\hline \multirow{2}{*}{ Sector } & \multirow{2}{*}{ ISIC } & \multicolumn{2}{|c|}{1975} & \multicolumn{3}{c|}{1985} & \multicolumn{2}{c|}{1995} & \multicolumn{2}{c|}{1999} \\
\cline { 3 - 10 } & & Empl. & VA & Empl. & VA & Empl. & VA & Empl. & VA \\
\hline Total & & 8.5 & 22.9 & 10.0 & 21.4 & 17.8 & 30.5 & 20.7 & 35.7 \\
Food products & 31 & 4.0 & 21.4 & 4.0 & 11.7 & 6.2 & 11.7 & 8.0 & 15.5 \\
Textiles & 32 & 7.8 & 26.5 & 11.3 & 29.1 & 23.5 & 25.1 & 24.8 & 37.5 \\
Wood & 33 & 11.2 & 23.9 & 11.7 & 13.3 & 8.0 & 13.2 & 10.4 & 20.0 \\
Paper & 34 & 7.1 & 16.9 & 5.6 & 9.6 & 16.3 & 32.1 & 14.3 & 21.6 \\
Chemicals & 35 & 16.9 & 28.6 & 14.0 & 27.7 & 16.7 & 43.0 & 17.7 & 45.4 \\
Non-metallic & & & & & & & & & \\
Minerals & 36 & 10.3 & 16.2 & 8.4 & 42.0 & 10.0 & 25.2 & 12.7 & 37.7 \\
Basic Metal Industries & 37 & 12.7 & 15.8 & 20.0 & 12.8 & 17.6 & 41.6 & 25.2 & 43.0 \\
Fabricated Metals & 38 & 18.1 & 22.7 & 18.2 & 29.7 & 34.1 & 48.4 & 44.2 & 57.4 \\
Other Manufacturing & 39 & 4.2 & 1.6 & 12.9 & 41.2 & 40.0 & 61.3 & 44.5 & 53.9 \\
\hline
\end{tabular}

Note: Empl. - Employment. VA- Value Added. 


\section{TABLE 2}

THE RATIOS OF AVERAGES WAGES IN FOREIGN-OWNED TO THOSE IN PRIVATEDOMESTICALLY OWNED PLANTS IN THE SAME YEAR BETWEEN 1975-1999 AT A 2DIGIT LEVEL OF ISIC

\begin{tabular}{|l|ll|ll|ll|ll|}
\hline \multirow{3}{*}{ Sector } & \multicolumn{3}{|c|}{1975} & \multicolumn{2}{|c|}{1985} & \multicolumn{2}{c|}{1990} & \multicolumn{2}{c|}{1999} \\
\cline { 2 - 9 } & $\begin{array}{l}\text { Blue- } \\
\text { collar }\end{array}$ & $\begin{array}{l}\text { White- } \\
\text { collar }\end{array}$ & $\begin{array}{l}\text { Blue- } \\
\text { collar }\end{array}$ & $\begin{array}{l}\text { White- } \\
\text { Collar }\end{array}$ & $\begin{array}{l}\text { Blue- } \\
\text { collar }\end{array}$ & $\begin{array}{l}\text { White- } \\
\text { collar }\end{array}$ & $\begin{array}{l}\text { Blue- } \\
\text { collar }\end{array}$ & $\begin{array}{l}\text { White- } \\
\text { collar }\end{array}$ \\
\hline Total & 2.80 & 3.11 & 2.27 & 1.81 & 1.67 & 1.70 & 1.44 & 1.68 \\
31 & 4.10 & 4.64 & 3.55 & 1.98 & 1.94 & 1.70 & 1.70 & 2.11 \\
32 & 2.21 & 3.15 & 1.46 & 1.55 & 1.13 & 1.28 & 1.31 & 1.69 \\
33 & 1.24 & 1.24 & 1.18 & 1.27 & 1.23 & 1.53 & 1.12 & 1.49 \\
34 & 2.56 & 4.44 & 1.74 & 2.42 & 1.80 & 1.18 & 1.79 & 1.22 \\
35 & 3.98 & 2.81 & 2.98 & 1.96 & 1.97 & 2.24 & 1.79 & 1.41 \\
36 & 4.69 & 4.75 & 2.66 & 2.02 & 2.63 & 2.06 & 2.19 & 1.71 \\
37 & 0.86 & 1.30 & 1.45 & 0.69 & 1.31 & 1.28 & 1.04 & 0.80 \\
38 & 1.58 & 1.48 & 1.85 & 1.73 & 1.49 & 1.54 & 1.29 & 1.96 \\
39 & 0.76 & 1.00 & 1.61 & 2.28 & 1.45 & 2.16 & 1.16 & 2.08 \\
\hline
\end{tabular}

Note: Average wages for private domestically-owned and foreign-owned plants have been calculated at a 3-digit level of ISIC and aggregated up to a 2-digit level of ISIC using shares of total blue-collar and white-collar employees as weights. See table 1 for sector names 
TABLE 3

THE NUMBER AND AVERAGE SIZE OF TAKEOVERS IN THE INDONESIAN MANUFACTURING SECTOR 1975-1999

\begin{tabular}{|c|c|c|c|c|c|c|}
\hline \multirow{3}{*}{ Sector } & \multirow{2}{*}{\multicolumn{2}{|c|}{ No. of Takeovers }} & \multicolumn{4}{|c|}{ Average Size } \\
\hline & & & \multicolumn{2}{|c|}{ Takeovers } & \multicolumn{2}{|c|}{ Existing Plants } \\
\hline & Domestic & Foreign & Foreign & Domestic & Foreign & Domestic \\
\hline \multicolumn{7}{|c|}{ 1975-1989 } \\
\hline Total & 408 & 326 & 250 & 210 & 358 & 103 \\
\hline 31 & 116 & 92 & 219 & 160 & 303 & 105 \\
\hline 32 & 96 & 80 & 265 & 243 & 732 & 105 \\
\hline 33 & 50 & 37 & 290 & 230 & 368 & 136 \\
\hline 34 & 15 & 6 & 42 & 79 & 263 & 78 \\
\hline 35 & 47 & 45 & 297 & 309 & 230 & 113 \\
\hline 36 & 28 & 19 & 192 & 264 & 423 & 54 \\
\hline 37 & 4 & 1 & 61 & 401 & 477 & 248 \\
\hline 38 & 48 & 39 & 283 & 150 & 318 & 110 \\
\hline 39 & 4 & 7 & 124 & 98 & 241 & 69 \\
\hline \multicolumn{7}{|c|}{$1990-1999$} \\
\hline Total & 637 & 917 & 426 & 418 & 539 & 153 \\
\hline 31 & 95 & 127 & 316 & 226 & 358 & 119 \\
\hline 32 & 177 & 226 & 681 & 701 & 1054 & 210 \\
\hline 33 & 85 & 92 & 367 & 363 & 471 & 188 \\
\hline 34 & 16 & 23 & 285 & 795 & 633 & 134 \\
\hline 35 & 90 & 150 & 281 & 233 & 283 & 158 \\
\hline 36 & 33 & 44 & 385 & 357 & 447 & 75 \\
\hline 37 & 8 & 13 & 177 & 224 & 292 & 221 \\
\hline 38 & 106 & 205 & 379 & 310 & 453 & 135 \\
\hline 39 & 27 & 37 & 481 & 339 & 568 & 120 \\
\hline
\end{tabular}

Note: Foreign takeovers are takeovers of domestically-owned plants and domestic takeovers are takeovers only of foreign-owned plants. Size is the average number of total employees. See table 1 for sector names. 


\section{TABLE 4}

\section{WAGES IN TARGET ESTABLISHMENTS RELATIVE TO ALL PRIVATE DOMESTIC ESTABLISHMENTS IN THE SAME YEAR}

\begin{tabular}{|c|c|c|c|c|c|}
\hline & \multicolumn{4}{|c|}{ Foreign takeovers of private-domestic plants Private-domestic takeovers of foreign plants } \\
\hline & & $\mathrm{T}-2$ & $\mathrm{~T}-1$ & $\mathrm{~T}-2$ & $\mathrm{~T}-1$ \\
\hline \multicolumn{6}{|c|}{ Unweighted } \\
\hline \multirow[t]{2}{*}{ Total } & Blue & 1.20 & 1.21 & 1.32 & 1.34 \\
\hline & & $(0.51)$ & $(0.47)$ & $(0.37)$ & $(0.33)$ \\
\hline \multirow[t]{2}{*}{ Total } & White & 0.97 & 0.99 & 0.96 & 0.96 \\
\hline & & $(0.37)$ & $(0.43)$ & $(0.40)$ & $(0.36)$ \\
\hline \multicolumn{6}{|c|}{ Weighted by sector employment } \\
\hline \multirow[t]{2}{*}{ Total } & Blue & 1.10 & 1.04 & 1.40 & 1.38 \\
\hline & & $(0.45)$ & $(0.44)$ & (0.37) & $(0.43)$ \\
\hline \multirow[t]{2}{*}{ Total } & White & 0.92 & 0.94 & 1.37 & 1.36 \\
\hline & & $(0.47)$ & $(0.48)$ & $(0.38)$ & $(0.35)$ \\
\hline \multirow{3}{*}{31} & By Sector & & & & \\
\hline & Blue & 0.99 & 1.02 & $2.02 * * *$ & $2.01 * *$ \\
\hline & & $(0.35)$ & $(0.33)$ & $(0.38)$ & $(0.42)$ \\
\hline \multirow[t]{2}{*}{31} & White & 0.75 & 0.76 & 1.74 & 1.60 \\
\hline & & $(0.36)$ & $(0.44)$ & $(0.48)$ & $(0.42)$ \\
\hline \multirow[t]{2}{*}{32} & Blue & 1.24 & 1.14 & 1.12 & 1.22 \\
\hline & & $(0.38)$ & $(0.44)$ & (0.39) & $(0.47)$ \\
\hline \multirow[t]{2}{*}{32} & White & 1.20 & 1.38 & 1.44 & 1.44 \\
\hline & & $(0.36)$ & $(0.44)$ & (0.37) & $(0.33)$ \\
\hline \multirow[t]{2}{*}{33} & Blue & 1.20 & 0.90 & 1.08 & 0.88 \\
\hline & & $(0.29)$ & $(0.39)$ & $(0.42)$ & $(0.35)$ \\
\hline \multirow[t]{2}{*}{33} & White & 0.80 & 0.80 & 1.28 & 1.27 \\
\hline & & $(0.38)$ & $(0.47)$ & $(0.31)$ & (0.39) \\
\hline \multirow[t]{2}{*}{35} & Blue & 1.18 & 1.18 & $1.86 * *$ & $1.56^{* *}$ \\
\hline & & $(0.45)$ & $(0.41)$ & $(0.37)$ & $(0.27)$ \\
\hline \multirow[t]{2}{*}{35} & White & 1.00 & 0.82 & 1.03 & 1.08 \\
\hline & & $(0.44)$ & $(0.43)$ & $(0.32)$ & $(0.32)$ \\
\hline \multirow[t]{2}{*}{38} & Blue & 0.88 & 0.96 & 1.01 & 1.09 \\
\hline & & $(0.32)$ & $(0.38)$ & $(0.44)$ & $(0.40)$ \\
\hline \multirow[t]{2}{*}{38} & White & 0.72 & 0.84 & 1.20 & 1.20 \\
\hline & & $(0.36)$ & $(0.33)$ & $(0.43)$ & $(0.29)$ \\
\hline
\end{tabular}

Note: T-2 (T-1) refers to two (one) years before the year of the takeover. Standard errors within brackets. ***) significant at the one percent level; **) significant at the five percent level; *)significant at the ten percent level. 
TABLE 5

\section{CHANGES AND LEVELS AFTER TAKEOVER IN THE RATIO OF WAGES IN TARGET ESTABLISHMENTS TO WAGES IN ALL DOMESTIC PRIVATELY-OWNED ESTABLISHMENTS IN THE SAME YEAR}

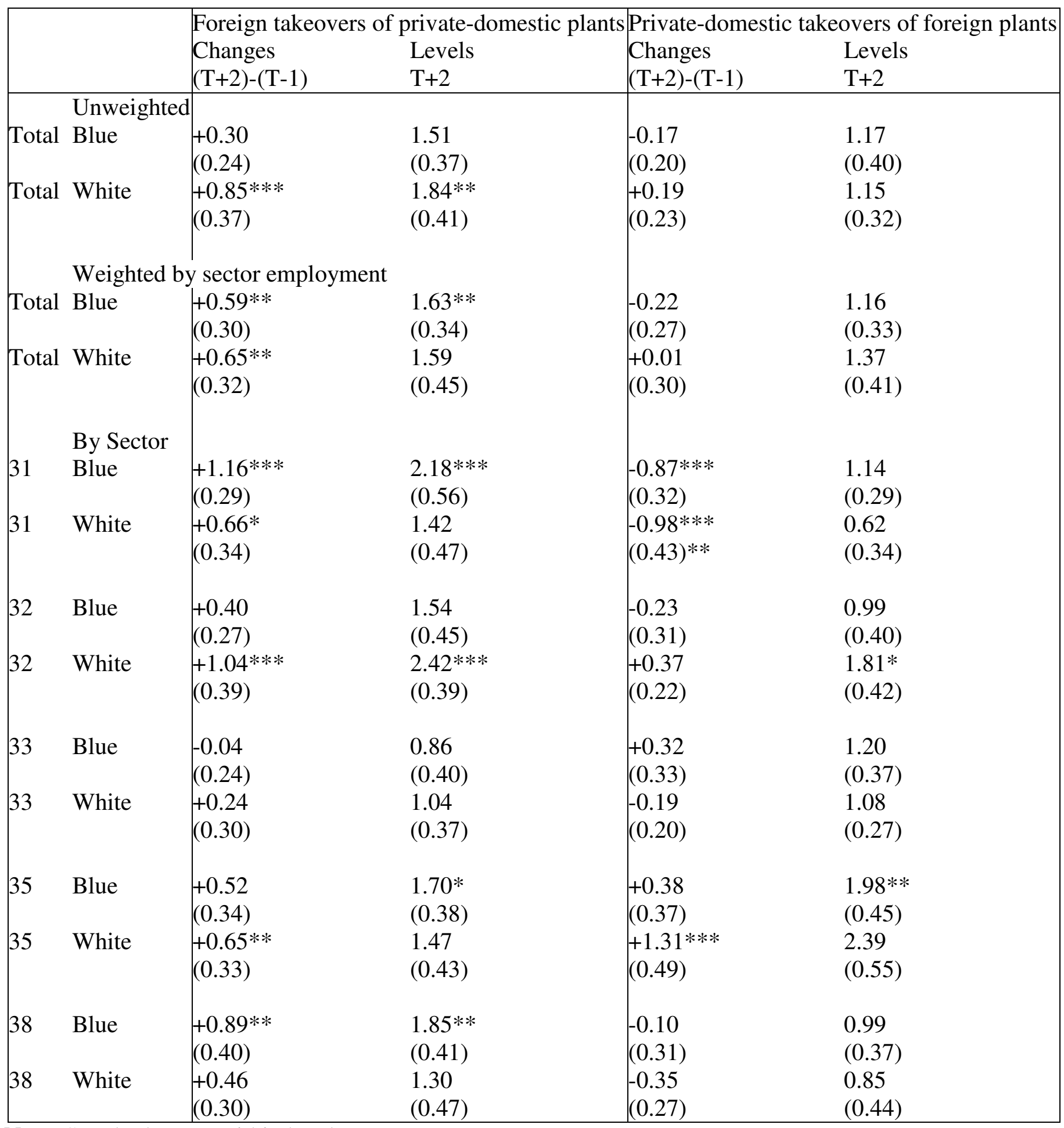

Note. Standard errors within brackets. $* * *)$ significant at the one percent level; $\left.{ }^{* *}\right)$ significant at the five percent level; *)significant at the ten percent level. 


\section{TABLE 6}

\section{THE RELATION OF AVERAGE PLANT WAGE TO OWNERSHIP AND PLANT CHARACTERISTICS 1975-1999 (DEPENDENT VARIABLE - LOG AVERAGE WAGE PER EMPLOYEE)}

\begin{tabular}{|c|c|c|c|c|c|c|}
\hline & $\begin{array}{l}\text { Blue } \\
\text { Collar } \\
\end{array}$ & $\begin{array}{l}\text { White } \\
\text { Collar }\end{array}$ & $\begin{array}{l}\text { Blue } \\
\text { Collar }\end{array}$ & $\begin{array}{l}\text { White } \\
\text { Collar }\end{array}$ & $\begin{array}{l}\text { Blue } \\
\text { Collar } \\
\end{array}$ & $\begin{array}{l}\text { White } \\
\text { Collar }\end{array}$ \\
\hline Constant & $\begin{array}{l}3.70 * * * \\
(0.01)\end{array}$ & $\begin{array}{l}4.61 * * * \\
(0.03)\end{array}$ & $\begin{array}{l}2.39 * * * \\
(0.02)\end{array}$ & $\begin{array}{l}2.90 * * * \\
(0.02)\end{array}$ & $\begin{array}{l}3.41 * * * \\
(0.03)\end{array}$ & $\begin{array}{l}3.86 * * * \\
(0.03)\end{array}$ \\
\hline Foreign owner & $\begin{array}{l}0.67 * * * \\
(0.03)\end{array}$ & $\begin{array}{l}0.92 * * * \\
(0.02)\end{array}$ & $\begin{array}{l}0.29 * * * \\
(0.01)\end{array}$ & $\begin{array}{l}0.43 * * * \\
(0.02)\end{array}$ & $\begin{array}{l}0.10 * * * \\
(0.01)\end{array}$ & $\begin{array}{l}0.21 * * * \\
(0.02)\end{array}$ \\
\hline $\begin{array}{l}\text { Government } \\
\text { owner }\end{array}$ & $\begin{array}{l}0.42 * * * \\
(0.04)\end{array}$ & $\begin{array}{l}0.09 * * * \\
(0.02)\end{array}$ & $\begin{array}{l}0.27 * * * \\
(0.02)\end{array}$ & $\begin{array}{l}-0.16 * * * \\
(0.02)\end{array}$ & $\begin{array}{l}0.01 * * * \\
(0.01)\end{array}$ & $\begin{array}{l}-0.01 * * * \\
(0.02)\end{array}$ \\
\hline $\begin{array}{l}\text { Energy per } \\
\text { worker }\end{array}$ & -- & -- & $\begin{array}{l}0.08 * * * \\
(0.00)\end{array}$ & $\begin{array}{l}0.06^{* * * *} \\
(0.00)\end{array}$ & $\begin{array}{l}0.07 * * * \\
(0.01)\end{array}$ & $\begin{array}{l}0.06 * * * \\
(0.01)\end{array}$ \\
\hline Inputs per worker & -- & -- & $\begin{array}{l}0.20 * * * \\
(0.00)\end{array}$ & $\begin{array}{l}0.18^{* * * *} \\
(0.00)\end{array}$ & $\begin{array}{l}0.14 * * * \\
(0.01)\end{array}$ & $\begin{array}{l}0.13 * * * \\
(0.00)\end{array}$ \\
\hline Size & -- & -- & $\begin{array}{l}0.01 * * * \\
(0.00)\end{array}$ & $\begin{array}{l}0.14 * * * \\
(0.03)\end{array}$ & $\begin{array}{l}-0.02 * * * \\
(0.00)\end{array}$ & $\begin{array}{l}0.07 * * * \\
(0.00)\end{array}$ \\
\hline Time dummies & estimated & estimated & estimated & estimated & estimated & estimated \\
\hline Industry dummies & estimated & estimated & estimated & estimated & -- & -- \\
\hline $\begin{array}{l}\text { Regional } \\
\text { dummies }\end{array}$ & estimated & estimated & estimated & estimated & -- & -- \\
\hline $\begin{array}{l}\text { Establishment } \\
\text { fixed effect }\end{array}$ & -- & -- & -- & -- & estimated & estimated \\
\hline R-square & 0.64 & 0.53 & 0.72 & 0.61 & 0.66 & 0.57 \\
\hline Number of plants & 47,297 & 40,838 & 45,448 & 39,531 & 45,448 & 39,531 \\
\hline $\begin{array}{l}\text { No of } \\
\text { observations }\end{array}$ & 336,576 & 269,536 & 316,031 & 256,852 & 316,031 & 256,852 \\
\hline
\end{tabular}

Note: Robust (Cluster at plant level) standard errors within brackets. ***) significant at the one percent level; **) significant at the five percent level; *)significant at the ten percent level. 


\section{TABLE 7}

THE RELATION OF AVERAGE PLANT WAGE TO DIFFERENT LEVELS OF FOREIGN OWNERSHIP AND DURING DIFFERENT TIME PERIODS (DEPENDENT VARIABLE - LOG AVERAGE WAGE PER EMPLOYEE)

\begin{tabular}{|c|c|c|c|c|c|c|}
\hline & $\begin{array}{l}\text { Blue } \\
\text { Collar }\end{array}$ & $\begin{array}{l}\text { White } \\
\text { Collar }\end{array}$ & Blue Collar & $\begin{array}{l}\text { White } \\
\text { Collar }\end{array}$ & Blue Collar & $\begin{array}{l}\text { White } \\
\text { Collar }\end{array}$ \\
\hline & & & $1975-86$ & $1975-86$ & $1987-99$ & 1987-99 \\
\hline Constant & $\begin{array}{l}3.41 \\
(0.01) * * *\end{array}$ & $\begin{array}{l}3.86 \\
(0.02) * * *\end{array}$ & $\begin{array}{l}3.19 \\
(0.02)^{* * *}\end{array}$ & $\begin{array}{l}3.75 \\
(0.03) * * *\end{array}$ & $\begin{array}{l}5.02 \\
(0.02) * * *\end{array}$ & $\begin{array}{l}5.51 \\
(0.03) * * *\end{array}$ \\
\hline Foreign owner & --- & --- & $\begin{array}{l}0.00 \\
(0.02)\end{array}$ & $\begin{array}{l}0.15 \\
(0.03) * * *\end{array}$ & $\begin{array}{l}0.13 \\
(0.01)^{* * *}\end{array}$ & $\begin{array}{l}0.22 \\
(0.02)^{* * *}\end{array}$ \\
\hline $\begin{array}{l}\text { Foreign majority } \\
\text { ownership }\end{array}$ & $\begin{array}{l}0.09 \\
(0.01)^{* * *}\end{array}$ & $\begin{array}{l}0.22 \\
(0.01) * * *\end{array}$ & --- & --- & --- & --- \\
\hline $\begin{array}{l}\text { Foreign minority } \\
\text { ownership }\end{array}$ & $\begin{array}{l}0.12 \\
(0.02) * * *\end{array}$ & $\begin{array}{l}0.16 \\
(0.02) * * *\end{array}$ & --- & --- & --- & --- \\
\hline Government owner & $\begin{array}{l}0.01 \\
(0.01)\end{array}$ & $\begin{array}{l}-0.01 \\
(0.01)\end{array}$ & $\begin{array}{l}-0.00 \\
(0.01)\end{array}$ & $\begin{array}{l}-0.06 \\
(0.02)^{* *}\end{array}$ & $\begin{array}{l}-0.00 \\
(0.01)\end{array}$ & $\begin{array}{l}-0.00 \\
(0.01)\end{array}$ \\
\hline Energy per worker & $\begin{array}{l}0.07 \\
(0.00)^{* * * *}\end{array}$ & $\begin{array}{l}0.06 \\
(0.00)^{* * * *}\end{array}$ & $\begin{array}{l}0.08 \\
(0.00)^{* * * *}\end{array}$ & $\begin{array}{l}0.07 \\
(0.00)^{* * * *}\end{array}$ & $\begin{array}{l}0.07 \\
(0.00)^{* * *}\end{array}$ & $\begin{array}{l}0.05 \\
(0.00)^{* * * *}\end{array}$ \\
\hline Inputs per worker & $\begin{array}{l}0.14 \\
(0.00) * * *\end{array}$ & $\begin{array}{l}0.13 \\
(0.00) * * *\end{array}$ & $\begin{array}{l}0.17 \\
(0.00) * * *\end{array}$ & $\begin{array}{l}0.15 \\
(0.00) * * *\end{array}$ & $\begin{array}{l}0.12 \\
(0.00) * * *\end{array}$ & $\begin{array}{l}0.11 \\
(0.00) * * *\end{array}$ \\
\hline Size & $\begin{array}{l}-0.02 \\
(0.00)^{* * * *}\end{array}$ & $\begin{array}{l}0.07 \\
(0.00) * * *\end{array}$ & $\begin{array}{l}-0.03 \\
(0.00)^{* * *}\end{array}$ & $\begin{array}{l}0.05 \\
(0.01)^{* * * *}\end{array}$ & $\begin{array}{l}-0.04 \\
(0.00) * * *\end{array}$ & $\begin{array}{l}0.05 \\
(0.00) * * *\end{array}$ \\
\hline Time dummies & Included & Included & Included & Included & Included & Included \\
\hline $\begin{array}{l}\text { Establishment fixed } \\
\text { effect }\end{array}$ & Included & Included & Included & Included & Included & Included \\
\hline R-square & 0.66 & 0.57 & 0.50 & 0.42 & 0.43 & 0.35 \\
\hline Number of plants & 45,448 & 39,531 & 18,854 & 16,048 & 38,718 & 33,545 \\
\hline No of observations & 316,031 & 256,852 & 94,084 & 73,509 & 221,947 & 183,343 \\
\hline
\end{tabular}

Note: Robust (Cluster at plant level) standard errors within brackets. ***) significant at the one percent level; **) significant at the five percent level; *)significant at the ten percent level. 


\section{TABLE 8}

\section{THE RELATION OF AVERAGE PLANT WAGE TO CHANGES IN OWNERSHIP AND PLANT CHARACTERISTICS 1975-1999 (DEPENDENT VARIABLE - LOG AVERAGE WAGE PER EMPLOYEE)}

\begin{tabular}{|c|c|c|c|c|c|c|}
\hline & Blue Collar & White Collar & Blue Collar & White Collar & Blue Collar & White Collar \\
\hline & OLS & OLS & OLS & OLS & Fixed effect & Fixed effect \\
\hline Constant & $\begin{array}{l}3.70 * * * \\
(001)\end{array}$ & $\begin{array}{l}4.61 * * * \\
(001)\end{array}$ & $\begin{array}{l}2.39 * * * \\
(001)\end{array}$ & $2.90 * * *$ & $3.42 * * *$ & $3.88 * * *$ \\
\hline Domestic, Pre & $0.25^{* * *}$ & $0.27 * * *$ & $0.09 * * *$ & $0.04 * * *$ & $-{ }_{--}$ & $\begin{array}{l}(0.02) \\
--\end{array}$ \\
\hline Foreign Takeover & $(0.01)$ & $(0.01)$ & $(0.01)$ & $(0.01)$ & & \\
\hline Foreign, Pre & $0.42 * * *$ & $0.49 * * *$ & $0.16 * * *$ & $0.16 * * *$ & -- & -- \\
\hline Domestic Takeover & $(0.01)$ & $(0.02)$ & $(0.02)$ & $(0.02)$ & & \\
\hline Foreign takeovers & $0.49 * * *$ & $0.74 * * *$ & $0.23 * * *$ & $0.37 * * *$ & $0.17 * * *$ & $0.28 * * *$ \\
\hline & $(0.01)$ & $(0.02)$ & $(0.01)$ & $(0.01)$ & $(0.01)$ & $(0.02)$ \\
\hline Foreign since 1975 & $\begin{array}{l}0.72 * * * \\
(0.01)\end{array}$ & $\begin{array}{l}0.99 * * * \\
(0.01)\end{array}$ & $\begin{array}{l}0.31 * * * \\
(0.01)\end{array}$ & $\begin{array}{l}0.48 * * * \\
(0.01)\end{array}$ & -- & -- \\
\hline Domestic takeovers & $\begin{array}{l}0.20 \text { *** } \\
(0.01)\end{array}$ & $\begin{array}{l}0.30 * * * \\
(0.01)\end{array}$ & $\begin{array}{l}0.06^{* * * *} \\
(0.01)\end{array}$ & $\begin{array}{l}0.10 * * * \\
(0.01)\end{array}$ & $\begin{array}{l}0.04 * * * \\
(0.01)\end{array}$ & $\begin{array}{l}0.07 * * * \\
(0.02)\end{array}$ \\
\hline Government owner & $\begin{array}{l}0.41 * * * \\
(0.01)\end{array}$ & $\begin{array}{l}0.09 * * * \\
(0.01)\end{array}$ & $\begin{array}{l}0.27 * * * \\
(0.01)\end{array}$ & $\begin{array}{l}-0.16^{* * * *} \\
(0.01)\end{array}$ & $\begin{array}{l}0.01 \\
(0.01)\end{array}$ & $\begin{array}{l}-0.01 \\
(0.01)\end{array}$ \\
\hline Energy per worker & -- & -- & $\begin{array}{l}0.08 * * * \\
(0.00)\end{array}$ & $\begin{array}{l}0.06^{* * *} \\
(0.00)\end{array}$ & $\begin{array}{l}0.07 * * * \\
(0.00)\end{array}$ & $\begin{array}{l}0.06^{* * * *} \\
(0.00)\end{array}$ \\
\hline Inputs per worker & -- & -- & $\begin{array}{l}0.20 * * * \\
(0.00)\end{array}$ & $\begin{array}{l}0.18 * * * \\
(0.00)\end{array}$ & $\begin{array}{l}0.14 * * * \\
(0.00)\end{array}$ & $\begin{array}{l}0.13 * * * \\
(0.00)\end{array}$ \\
\hline Size & -- & -- & $\begin{array}{l}0.01 * * * \\
(0.00)\end{array}$ & $\begin{array}{l}0.14 * * * \\
(0.00)\end{array}$ & $\begin{array}{l}-0.02 * * * \\
(0.00)\end{array}$ & $\begin{array}{l}0.07 * * * \\
(0.00)\end{array}$ \\
\hline Time dummies & estimated & estimated & Estimated & estimated & estimated & estimated \\
\hline Industry dummies & estimated & estimated & Estimated & estimated & -- & -- \\
\hline Regional dummies & estimated & estimated & Estimated & estimated & -- & -- \\
\hline Fixed effect & & -- & & -- & estimated & estimated \\
\hline R-square & 0.64 & 0.53 & 0.72 & 0.61 & 0.66 & 0.56 \\
\hline No of plants & 47,297 & 40,838 & 45,448 & 39,531 & 45,448 & 39,531 \\
\hline No of observations & 336,576 & 269,536 & 316,031 & 256,852 & 316,031 & 256,852 \\
\hline
\end{tabular}

Note: Robust (Cluster at plant level) standard errors within brackets. ***) significant at the one percent level; **) significant at the five percent level; *)significant at the ten percent level. Domestic takeovers refers only to takeovers of foreign-owned plants. 
TABLE 9

THE RELATION OF AVERAGE PLANT WAGE TO OWNERSHIP CHANGES AND PLANT CHARACTERISTICS AT A SECTOR LEVEL (DEPENDENT VARIABLE - LOG AVERAGE WAGE PER EMPLOYEE)

\begin{tabular}{|c|c|c|c|c|c|c|c|c|c|c|}
\hline & $\begin{array}{l}\text { Food Products (ISIC } \\
31 \text { ) }\end{array}$ & $\begin{array}{l}\text { cts (ISIC } \\
\text { White } \\
\text { Collar }\end{array}$ & $\begin{array}{l}\text { Blue } \\
\text { Collar }\end{array}$ & Textiles (ISIC 32) & \multicolumn{2}{|c|}{$\begin{array}{l}\text { Wood Products } \\
\text { (ISIC 33) }\end{array}$} & \multicolumn{2}{|c|}{ Chemicals (ISIC 35) } & \multicolumn{2}{|c|}{$\begin{array}{l}\text { Fabricated Metal } \\
\text { Products (ISIC 38) }\end{array}$} \\
\hline Constant & $\begin{array}{l}2.76 * * * \\
(0.04)\end{array}$ & $\begin{array}{l}3.52 * * * \\
(0.04)\end{array}$ & $\begin{array}{l}3.63 * * * \\
(0.04)\end{array}$ & $\begin{array}{l}4.05 * * * \\
(0.04)\end{array}$ & $\begin{array}{l}3.64 * * * \\
(0.05)\end{array}$ & $\begin{array}{l}3.98 * * * \\
(0.07)\end{array}$ & $\begin{array}{l}3.79 * * * \\
(0.05)\end{array}$ & $\begin{array}{l}4.06 * * * \\
(0.06)\end{array}$ & $\begin{array}{l}4.13 * * * \\
(0.06)\end{array}$ & $\begin{array}{l}4.40 * * * \\
(0.08)\end{array}$ \\
\hline Foreign takeovers & $\begin{array}{l}0.24 * * * \\
(0.04)\end{array}$ & $\begin{array}{l}0.24 * * * \\
(0.04)\end{array}$ & $\begin{array}{l}0.11 * * * \\
(0.03)\end{array}$ & $\begin{array}{l}0.24 * * * \\
(0.04)\end{array}$ & $\begin{array}{l}0.12 * * * \\
(0.04)\end{array}$ & $\begin{array}{l}0.20 * * * \\
(0.06)\end{array}$ & $\begin{array}{l}0.13 * * * \\
(0.04)\end{array}$ & $\begin{array}{l}0.23 * * * \\
(0.05)\end{array}$ & $\begin{array}{l}0.18 * * * \\
(0.05)\end{array}$ & $\begin{array}{l}0.44 * * * \\
(0.07)\end{array}$ \\
\hline Domestic & $0.08 *$ & $0.13 * * *$ & $0.15 * * *$ & $0.13 * * *$ & $0.07 *$ & 0.01 & $-0.17 * * *$ & -0.07 & $-0.06 * *$ & $-0.01 * * *$ \\
\hline takeovers & $(0.03)$ & $(0.0)$ & $(0.03)$ & $(0.03)$ & $(0.04)$ & $(0.05)$ & $(0.03)$ & $(0.05)$ & $(0.04)$ & $(0.04)$ \\
\hline Government & -0.02 & -0.02 & 0.02 & 0.04 & 0.01 & 0.02 & 0.01 & -0.01 & $0.07 * * *$ & $-0.11 * * *$ \\
\hline Owner & $(0.01)$ & $(0.02)$ & $(0.03)$ & $(0.04)$ & $(0.04)$ & $(0.04)$ & $(0.02)$ & $(0.04)$ & $(0.03)$ & $(0.04)$ \\
\hline Energy per worker & $\begin{array}{l}0.11 * * * \\
(0.00)\end{array}$ & $\begin{array}{l}0.08 * * * \\
(0.01)\end{array}$ & $\begin{array}{l}0.06 * * * \\
(0.00)\end{array}$ & $\begin{array}{l}0.04 * * * \\
(0.01)\end{array}$ & $\begin{array}{l}0.09 * * * \\
(0.01)\end{array}$ & $\begin{array}{l}0.06 * * * \\
(0.02)\end{array}$ & $\begin{array}{l}0.04 * * * \\
(0.01)\end{array}$ & $\begin{array}{l}0.04 * * \\
(0.02)\end{array}$ & $\begin{array}{l}0.04 * * * \\
(0.01)\end{array}$ & $\begin{array}{l}0.04 * * * \\
(0.01)\end{array}$ \\
\hline Inputs per worker & $\begin{array}{l}0.17 * * * \\
(0.01)\end{array}$ & $\begin{array}{l}0.13 * * * \\
(0.00)\end{array}$ & $\begin{array}{l}0.11 * * * \\
(0.01)\end{array}$ & $\begin{array}{l}0.09 * * * \\
(0.00)\end{array}$ & $\begin{array}{l}0.15 * * * \\
(0.01)\end{array}$ & $\begin{array}{l}0.13 * * * \\
(0.02)\end{array}$ & $\begin{array}{l}0.11 * * * \\
(0.00)\end{array}$ & $\begin{array}{l}0.15 * * * \\
(0.02)\end{array}$ & $\begin{array}{l}0.12 * * * \\
(0.00)\end{array}$ & $\begin{array}{l}0.11 * * * \\
(0.00)\end{array}$ \\
\hline Size & $\begin{array}{l}-0.04 * * * \\
(0.00)\end{array}$ & $\begin{array}{l}0.04 * * * \\
(0.01)\end{array}$ & $\begin{array}{l}0.01 \\
(0.00)\end{array}$ & $\begin{array}{l}0.09 * * * \\
(0.01)\end{array}$ & $\begin{array}{l}-0.00 \\
(0.01)\end{array}$ & $\begin{array}{l}0.07 * * * \\
(0.01)\end{array}$ & $\begin{array}{l}-0.02 * * * \\
(0.01)\end{array}$ & $\begin{array}{l}0.04 * * \\
(0.02)\end{array}$ & $\begin{array}{l}-0.04 * * * \\
(0.01)\end{array}$ & $\begin{array}{l}0.07 * * * \\
(0.01)\end{array}$ \\
\hline Time dummies & estimated & estimated & estimated & estimated & estimated & estimated & estimated & estimated & estimated & estimated \\
\hline Fixed effect & estimated & estimated & estimated & estimated & estimated & estimated & estimated & estimated & estimated & estimated \\
\hline R-square & 0.66 & 0.55 & 0.77 & 0.63 & 0.56 & 0.49 & 0.68 & 0.54 & 0.70 & 0.58 \\
\hline No of plants & 11,677 & 10,024 & 11,304 & 8,967 & 6,609 & 5,991 & 5,144 & 4,954 & 4,929 & 4,608 \\
\hline No of observations & 87,632 & 67,982 & 74,580 & 54,155 & 35,455 & 31,207 & 36,925 & 34,615 & 32,929 & 30,069 \\
\hline
\end{tabular}

Note: Robust (Cluster at plant level) standard errors within brackets. ***) significant at the one percent level; **) significant at the five percent level; *)significant at the ten percent level. Domestic takeovers refers only to takeovers of foreign-owned plants. 